\title{
Blodtrykksnivå i en norsk befolkning - betydningen av arv og livsstil
}

\author{
Sammendrag \\ Bakgrunn. Arv og livsstil er relatert \\ til blodtrykksnivå, hjerte- og karsyk- \\ dommer og død, men presise risiko- \\ estimater for hypertensjon relatert til \\ arv, kjønn og alder mangler. Hensikten \\ med studien var å finne prevalens av \\ arvede og livsstilsrelaterte faktorer \\ og vurdere disse faktorenes assosia- \\ sjon med hypertensjon, spesifisert \\ for alder og kjønn.
}

Materiale og metode. Studien var basert på personer i alderen 20-79 år som møtte til den andre helseundersøkelsen i Nord-Trøndelag (HUNT 2). I beregningene av forekomst av hypertensjon inkluderte vi personer med målt blodtrykk og kroppsmasseindeks som hadde besvart spørsmål om egen blodtrykksmedikasjon og hypertensjon i nærmeste slekt. I en undergruppe som ikke var medikamentelt behandlet for hypertensjon, ble blodtrykk modellert med multippel lineær regresjon som funksjon av livsstilsrelaterte faktorer, kardiovaskulær sykdom og diabetes og forekomst av disse i nærmeste slekt.

Resultater. 42117 personer ble inkludert. Forekomsten av hypertensjon varierte fra $7 \%$ til $85 \%$ i ulike aldersgrupper og mellom kjønnene. $16 \%$ var i fedmegruppen og $45 \%$ hadde hypertensjon i slekten. Stratifisert for alder, kjønn og hypertensjon i slekten var fedme forbundet med inntil fire ganger $ø k t$ forekomst av hypertensjon. Den relative risiko for hypertensjon var spesielt høy hos unge kvinner med hypertensjon i slekten og fedme. Unge kvinner og menn med fedme hadde henholdsvis ca. $10 \mathrm{~mm} \mathrm{Hg}$ og $7 \mathrm{~mm} \mathrm{Hg}$ høyere systolisk blodtrykk enn personer uten fedme, mens hypertensjon i slekten var forbundet med ca. $3 \mathrm{~mm} \mathrm{Hg} \mathrm{høyere} \mathrm{systolisk}$ blodtrykk hos begge kjønn.

Fortolkning. Hypertensjon i slekten og fedme er assosiert med høyt blodtrykk. Sammenhengen er spesielt tydelig i ung alder, hvor det for kvinner også er en positiv interaksjon mellom disse to faktorene.

\section{Morten Klouman}

Det medisinske fakultet

Norges teknisk-naturvitenskapelige universitet

Arne Åsberg

Avdeling for medisinsk biokjemi

St. Olavs hospital

\section{Tor-Erik Widerøe}

tor-erik.wideroe@ntnu.no

Institutt for kreftforskning og molekylærmedisin Det medisinske fakultet

Norges teknisk-naturvitenskapelige universitet

Hypertensjon er en av de ti viktigste faktorer for den globale sykdomsbelastning og er estimert til å være årsak til mer en sju millioner dødsfall årlig. Det tilsvarer omtrent $13 \%$ av årlige dødsfall på verdensbasis (1). Den tredje EUROASPIRE-undersøkelsen er en tversnittsstudie av forebyggende tiltak for pasienter med koronarsykdom. Sammenliknet med tidligere gjennomførte EUROASPIRE I og II konkluderer den med at det fortsatt bare er en tredel av pasientene som blir henvist til livsstilsprogrammer, mens medikamentforskrivingen øker (2).

Både arv og livsstil er relatert til blodtrykksnivå, hjerte- og karsykdommer og død (3). Internasjonale retningslinjer angir estimater for absolutt risiko for hjerte- og karsykdom og død relatert til blodtrykksnivå og antall risikofaktorer (4-6). Arv inngår som regel ikke i disse beregningene av estimatene. Relativ risiko relatert til kjønn og alder er mindre kjent, men spesielt viktig for yngre aldersgrupper med lav absolutt risiko og hvor forventet effekt på antall leveår er størst (7). Hensikten med denne studien var å undersøke prevalens av arvede og livsstilsrelaterte risikofaktorer for kardiovaskulær sykdom og død og vurdere faktorenes assosiasjon med forekomsten av hypertensjon for begge kjønn og i ulike aldersgrupper.

\section{Materiale og metode \\ Studiepopulasjonen}

Den andre helseundersøkelsen i Nord-Trøndelag (HUNT 2) ble gjennomført fra og med 1995 til og med 1997. I alt møtte 66140 personer $(71,2 \%$ av de inviterte) i alderen 19-100 år. Deltakerne fikk målt blodtrykk, midjeomkrets, høyde og vekt og besvarte et spørreskjema om egen helse, livsstil, sosiale forhold og sykdommer i slekten (8). I denne studien er kun deltakere i alderen 20-79 år inkludert $(n=62296)$, ettersom oppmøtet var relativt lavt i høyere aldersklasser (8).
Nedre aldersgrense ble satt til 20 år, da definisjonen av høy utdanning var gjennomført tre år på videregående skole.

\section{Blodtrykk}

Blodtrykket ble målt med et automatisk oscillometrisk apparat, Dinamap 845XT (Criticon), av spesielt instruerte sykepleiere og teknikere. Mansjettstørrelsen ble tilpasset etter måling av overarmens omkrets. Blodtrykksmålingen ble gjort etter to minutters hvile i sittende stilling med blodtrykksmansjetten påmontert. Blodtrykket ble målt tre ganger med ett minutts intervaller. Gjennomsnittet av andre og tredje måling ble benyttet i beregningene. Hypertensjon ble definert som systolisk blodtrykk $\geq 140 \mathrm{~mm} \mathrm{Hg} \mathrm{og} /$ eller diastolisk blodtrykk $\geq 90 \mathrm{~mm} \mathrm{Hg}$ eller medikamentelt behandlet blodtrykk.

\section{Variabler}

Deltakerne anga om de hadde eller hadde hatt angina pectoris, hjerteinfarkt, hjerneslag, diabetes eller medikamentelt behandlet hypertensjon. De skulle videre svare på om det var forekomst av følgende sykdommer hos foreldre, søsken eller barn: hjerneslag, hjerteinfarkt før fylte 60 år, diabetes og hypertensjon.

Kroppsmasseindeks (BMI, $\mathrm{kg} / \mathrm{m}^{2}$ ) ble kategorisert $\mathrm{i}<25,25-29$ og $\geq 30$, definert som henholdsvis normal vekt, overvekt og fedme (1).

Fysisk aktivitet var i spørreskjemaet gradert ut fra hyppighet, varighet og intensitet (8). I analysen ble nivået av fysisk aktivitet dikotomisert til høyt og lavt. Høyt aktivitetsnivå ble valgt som referansekategori og ble definert som aktivitet med andpustenhet og svette $\geq 1$ time per uke (9). Dikotomisering ble valgt fordi tidligere analyser med tre kate-

\section{Hovedbudskap}

- Overvekt, fedme og hypertensjon i slekten forekom hyppig og var assosiert med hypertensjon.

- Den absolutt økte prevalens av hypertensjon relatert til disse faktorene synes å være relativt lik for begge kjønn i alle aldersgrupper.

- Den økte relative risiko for hypertensjon er imidlertid betydelig høyere $i$ ung alder og spesielt hos kvinner 
gorier for fysisk aktivitet har gitt tilsvarende resultater som inndeling i to nivåer $(9,10)$.

Utdanning ble klassifisert som høy eller lav. Høy utdanning ble definert som gjennomført allmennfaglig videregående skole eller utdanning av høyere grad. Lav utdanning ble definert som grunnskole, realskole eller yrkesfaglig videregående skole.

Røykestatus ble angitt som nåværende røyker, tidligere røyker eller aldri røykt, mens alkoholbruk ble klassifisert i ikke-bruker eller bruker. Ikke-brukerne var de som i spørreskjemaet anga at de aldri drakk alkohol. dien.

Blod- og urinanalyser inngikk ikke i stu-

\section{Statistikk og analyse}

I analysene inkluderte vi deltakere som hadde registrerte måleverdier for blodtrykk og kroppsmasseindeks og i tillegg hadde besvart spørsmål om egen blodtrykksmedikasjon og hypertensjon i slekten. Disse ble kategorisert etter BMI-nivå og status for hypertensjon i slekten. Prevalens av hypertensjon relatert til disse kategoriene ble beregnet for ti års aldersgrupper og for hvert kjønn. Eksakt Fishers 95\% konfidensintervall for prevalens ble beregnet ved hjelp av programmet PEPI versjon 4.0.

Mulig interaksjon på en additiv skala mellom risikofaktorene hypertensjon i slekten og kroppsmasseindeks dikotomisert med grenseverdi for fedme $\left(\geq 30 \mathrm{~kg} / \mathrm{m}^{2}\right)$ ble undersøkt ved å beregne økning av relativ risiko (med tilhørende 95\% konfidensintervall) grunnet interaksjon (11). Har man to risikofaktorer, A og $\mathrm{B}$, og betegner relativ risiko når bare én av risikofaktorene er til stede som henholdsvis $\mathrm{RR}_{\mathrm{A}+\mathrm{B}-} \mathrm{og} \mathrm{RR}_{\mathrm{A}-\mathrm{B}+}$, relativ risiko når begge er til stede som $\mathrm{RR}_{\mathrm{A}+\mathrm{B}+}$ og når ingen er til stede som $\mathrm{RR}_{\mathrm{A}-\mathrm{B}-}$, er avvik fra additivitet $\mathrm{RERI}=$ $\left(\mathrm{RR}_{\mathrm{A}+\mathrm{B}+}-\mathrm{RR}_{\mathrm{A}-\mathrm{B}-}\right)-\left(\mathrm{RR}_{\mathrm{A}+\mathrm{B}-}-\mathrm{RR}_{\mathrm{A}-\mathrm{B}-}\right)-$ $\left(R_{A_{-B^{+}}}-R_{\mathrm{A}_{-}-}\right)(9)$. Hvis det ikke er inter- aksjon, er RERI $=0$. Hvis for eksempel den samlede relative risiko er 6 og RERI $=2$, betyr det at interaksjon har økt den relative risiko med 2, fra 4 til 6 .

I et underutvalg som hadde angitt at de ikke brukte blodtrykksmedikasjon og hvor det forelå data om alder, kjønn, blodtrykk, kroppsmasseindeks, egen sykdom, hypertensjon i slekten, utdanningsstatus, fysisk aktivitetsnivå, røykestatus og alkoholforbruk, undersøkte vi hvor sterkt de ulike variablene var assosiert med blodtrykksnivå ved hjelp av multippel lineær regresjon. Av de variablene som var tilgjengelige i databasen, valgte vi dem vi mente var relevante for problemstillingen og som alle inngikk i analysene. Variablene ble ikke forhåndsutvalgt på bakgrunn av univariabel analyse. Grad av samvariasjon mellom sykdommene i slekten og egenopplevd sykdom ble vurdert ved å beregne phikoeffisienter. Kroppsmasseindeks ble omgjort til en semikvantitativ variabel i tre trinn, da dette ga en rettlinjet sammenheng med blodtrykksnivået. Analysen ble gjort separat for hvert kjønn med systolisk og diastolisk blodtrykk som avhengige variabler.

I alle analyser ble p-verdier $<0,05$ ansett som statistisk signifikante. Studien var godkjent av regional komité for medisinsk og helsefaglig forskningsetikk.

\section{Resultater}

Av de 62296 deltakerne i HUNT 2 som var aktuelle for deltakelse i studien, ble 20179 ekskludert pga. mangelfulle datasett. Denne studien inkluderer derfor de 42117 deltakerne $(54,6 \%$ kvinner $)$ der det forelå opplysninger om målt blodtrykk, bruk av blodtrykksmedikamenter, kroppsmasseindeks og hypertensjon i slekten. Karakteristikk av disse er gjengitt i tabell 1. De som brukte antihypertensiver, hadde gjennomsnittlig høyere blod- trykk enn blodtrykket i gruppen som helhet. Blant de 20179 ekskluderte deltakerne var blodtrykket registrert hos 19787 . Forekomsten av hypertensjon i hver aldersgruppe var den samme som $i$ den inkluderte gruppen hos begge kjønn (data ikke vist).

Prevalens av hypertensjon i ulike alders- og BMI-klasser for kvinner og menn med og uten hypertensjon i slekten fremgår av e-tabell 2 og figur 1. Prevalensen økte med alder og kroppsmasseindeks for begge kjønn. Ved samme alders- og BMI-klasse var prevalensen høyest hos dem som hadde hypertensjon i slekten. Nesten alle over 70 år med hypertensjon $i$ slekten og fedme var hypertensive. Tilsynelatende var det en additiv effekt for dem som hadde begge disse risikofaktorene (fig 1, e-tab 2 ). For begge kjønn i alle aldersgrupper var hypertensjon i slekten assosiert omtrent like sterkt med økning i hypertensjonsforekomst som det å gå opp en BMI-klasse.

Figur 2 viser relativ risiko for hypertensjon i ulike aldersgrupper med hypertensjon i slekten eller fedme eller begge deler i forhold til referansepersoner i tilsvarende aldersgruppe med kroppsmasseindeks $<25 \mathrm{~kg} / \mathrm{m}^{2}$ og uten hypertensjon i slekten. Unge (20-39 år) kvinner med fedme hadde ca. fire ganger høyere forekomst av hypertensjon enn de med kroppsmasseindeks $<25 \mathrm{~kg} / \mathrm{m}^{2}$. Tilsvarende ses doblet forekomst for menn (e-tab 2, fig 2). Kvinner og menn i aldersgruppen 20-29 år med både hypertensjon i slekten og fedme hadde henholdsvis 7,4 og 2,5 ganger større forekomst av hypertensjon enn referansegruppen. For kvinner i alderen 20-29 år var økningen i relativ risiko på grunn av interaksjon 2,24 (95\% KI 0,36-4,44), hvilket betyr at interaksjon mellom de to risikofaktorene økte den relative risikoen fra 5,16 til 7,4. For menn var det ingen statistisk signifikant interaksjon.

Av de 42117 deltakerne var det 30577

\begin{tabular}{|c|c|c|c|}
\hline Variabel & Totalt $(n=42117)$ & Kvinner ( $n=22976$ ) & Menn $(n=19141)$ \\
\hline Alder (år) & $46,7(15,3)$ & $46,1(15,3)$ & $47,3(15,3)$ \\
\hline Systolisk blodtrykk (mm Hg) & $135,5(20,4)$ & $132,5(21,6)$ & $139,0(17,9)$ \\
\hline Diastolisk blodtrykk (mm Hg) & $79,6(11,9)$ & $77,9(11,8)$ & $81,7(11,7)$ \\
\hline Blodtrykk $\geq 140 / 90$ mm Hg eller blodtrykksbehandlet (\%) & 40,4 & 34,1 & 48,0 \\
\hline \multicolumn{4}{|l|}{ Blodtrykksbehandlet (\%) } \\
\hline Andel av hypertensive & 24,1 & 29,2 & 19,8 \\
\hline Andel av alle deltakere & 9,7 & 9,9 & 9,5 \\
\hline Systolisk blodtrykk hos blodtrykksbehandlede (mm Hg) & $154,6(21,6)$ & $156,0(21,9)$ & $152,9(21,1)$ \\
\hline Diastolisk blodtrykk hos blodtrykksbehandlede (mm Hg) & $88,3(12,3)$ & $87,3(12,6)$ & $89,5(11,8)$ \\
\hline Hypertensjon i slekten (\%) & 44,5 & 48,4 & 39,9 \\
\hline Kroppsmasseindeks $\left(\mathrm{kg} / \mathrm{m}^{2}\right)$ & $26,3(4,1)$ & $26,1(4,5)$ & $26,4(3,5)$ \\
\hline \multicolumn{4}{|l|}{ BMI-nivå (kg/m²) (\%) } \\
\hline$<25$ & 41,2 & 46,1 & 35,5 \\
\hline $25-29$ & 42,9 & 36,5 & 50,6 \\
\hline$\geq 30$ & 15,9 & 17,5 & 14,0 \\
\hline
\end{tabular}


som hadde angitt at de ikke brukte blodtrykksmedikasjon og som dessuten hadde besvart alle spørsmål. I dette underutvalget undersøkte vi hvor sterkt de ulike variablene var assosiert med blodtrykksnivå. Karakteristikk av disse personene er vist i tabell 3 . Resultatene av regresjonsanalysen for sammenhengen mellom de ulike risikofaktorer og systolisk blodtrykk er vist i tabell 4. For både systolisk og diastolisk blodtrykk (data kun vist for systolisk blodtrykk) og for begge kjønn var faktorene alder, hypertensjon i slekten og BMI-nivå sterkest assosiert med blodtrykket. De med hypertensjon i slekten hadde ca. $3 \mathrm{~mm} \mathrm{Hg}$ høyere systolisk blodtrykk enn de uten hypertensjon i slekten. Kvinner og menn med BMI $25-29 \mathrm{~kg} / \mathrm{m}^{2}$ hadde henholdsvis ca. $4 \mathrm{~mm} \mathrm{Hg}$ og 3,5 mm $\mathrm{Hg}$ høyere systolisk blodtrykk enn de med BMI $<25 \mathrm{~kg} / \mathrm{m}^{2}$. Ved BMI $\geq 30 \mathrm{~kg} / \mathrm{m}^{2}$ var blodtrykket henholdsvis ca. $10 \mathrm{~mm} \mathrm{Hg} \mathrm{og}$ $7 \mathrm{~mm} \mathrm{Hg}$ høyere.

Lav utdanning var assosiert med ca. 2 mm Hg høyere systolisk blodtrykk hos begge kjønn. Fysisk aktivitet var ikke statistisk signifikant assosiert med blodtrykk. Røykere hadde ca. 1-3 $\mathrm{mm} \mathrm{Hg}$ lavere systolisk blodtrykk enn ikke-røykere, og kvinner som oppga at de bruke alkohol, hadde ca. $1 \mathrm{~mm}$ $\mathrm{Hg}$ lavere systolisk blodtrykk enn ikke-brukere. Diastolisk blodtrykk (ikke vist) viste generelt sett samme tendenser som systolisk blodtrykk, men det var mindre uttalte forskjeller. Samvariasjonen mellom sykdommene i slekten og egenopplevd sykdom var lav - størst for diabetes, der korrelasjonskoeffisienten var 0,107 .

\section{Diskusjon}

Overvekt, fedme og hypertensjon i slekten er hyppig forekommende og sterkt assosiert med økt blodtrykksnivå og forekomst av hypertensjon. Assosiasjonen er mest uttalt hos kvinner. Det er vel kjent at overvekt og spesielt fedme er assosiert med forhøyet blodtrykk og økt risiko for død $(12,13)$, likeledes assosiasjonen mellom hypertensjon $\mathrm{i}$ slekten og blodtrykksnivå (14). Vårt bidrag er å kvantitere disse sammenhengene for begge kjønn og i ulike aldersgrupper. Effekten av fedme var ca. $10 \mathrm{~mm} \mathrm{Hg}$ og $7 \mathrm{~mm} \mathrm{Hg}$ høyere blodtrykk hos henholdsvis kvinner og menn. Dette kan stemme overens med at vektreduksjon er angitt å senke systolisk og diastolisk blodtrykk med $1 \mathrm{~mm} \mathrm{Hg}$ per kilo (15). Til sammenlikning er den blodtrykksreduserende effekten av ett antihypertensivum i gjennomsnitt ca. $10 \mathrm{~mm} \mathrm{Hg} \mathrm{(16).}$

I denne tverrsnittsundersøkelsen har vi undersøkt prevalens av hypertensjon for begge kjønn i ulike aldersgrupper relatert til selvrapportert hypertensjon i slekten og BMI-nivå. For begge kjønn og i alle aldersgrupper synes assosiasjonen mellom begge faktorene og prevalens av hypertensjon å være lik. Effekten av å ha begge faktorene er tilsynelatende additiv. Det å ha høyt blodtrykk i slekten er assosiert med forhøyet pre-
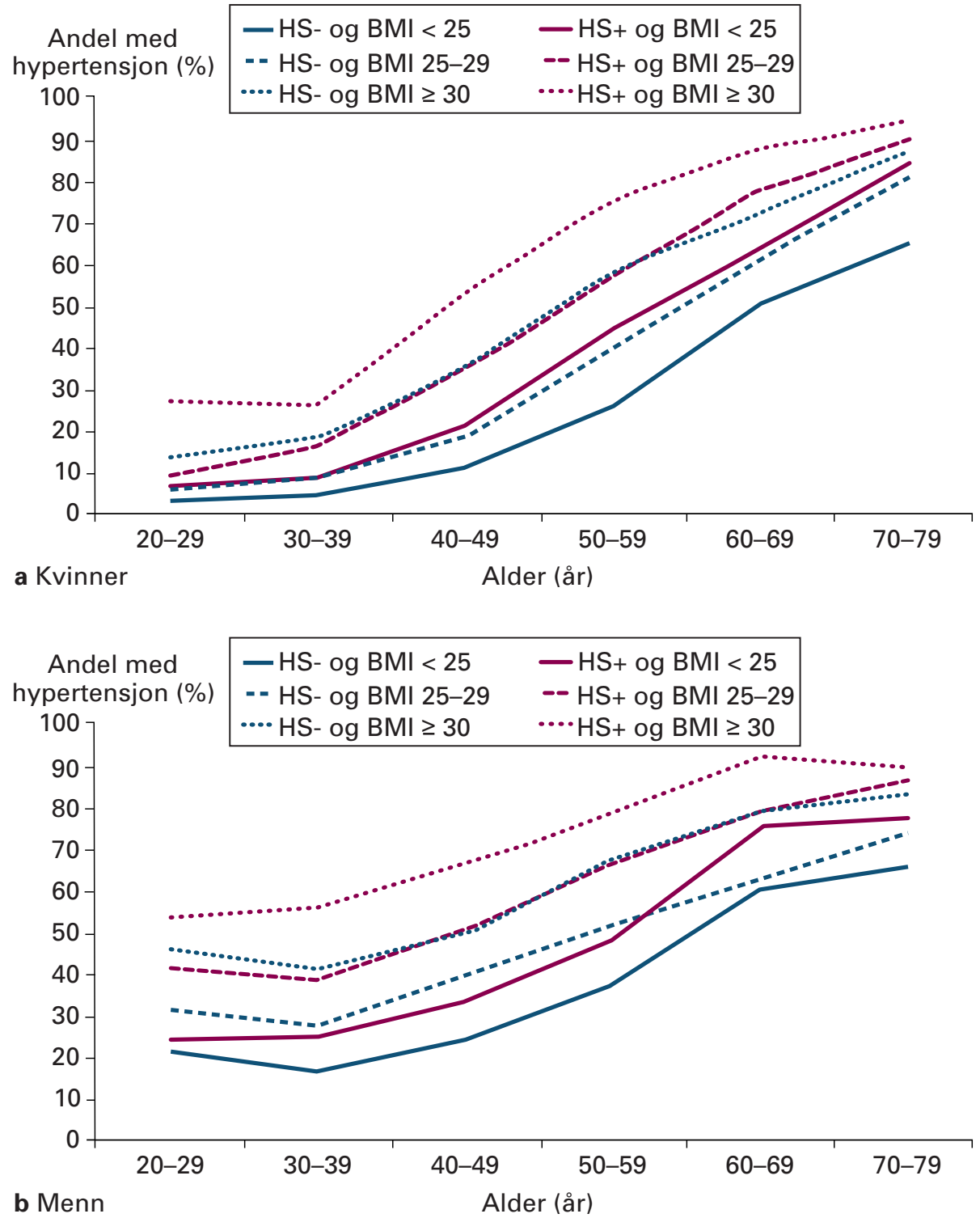

Figur 1 Alders-og kjønnsrelatert forekomst av hypertensjon for tre BMI-kategorier med (+) eller uten (-) hypertensjon i slekten (HS) for al kvinner og b) menn. $n=42117$

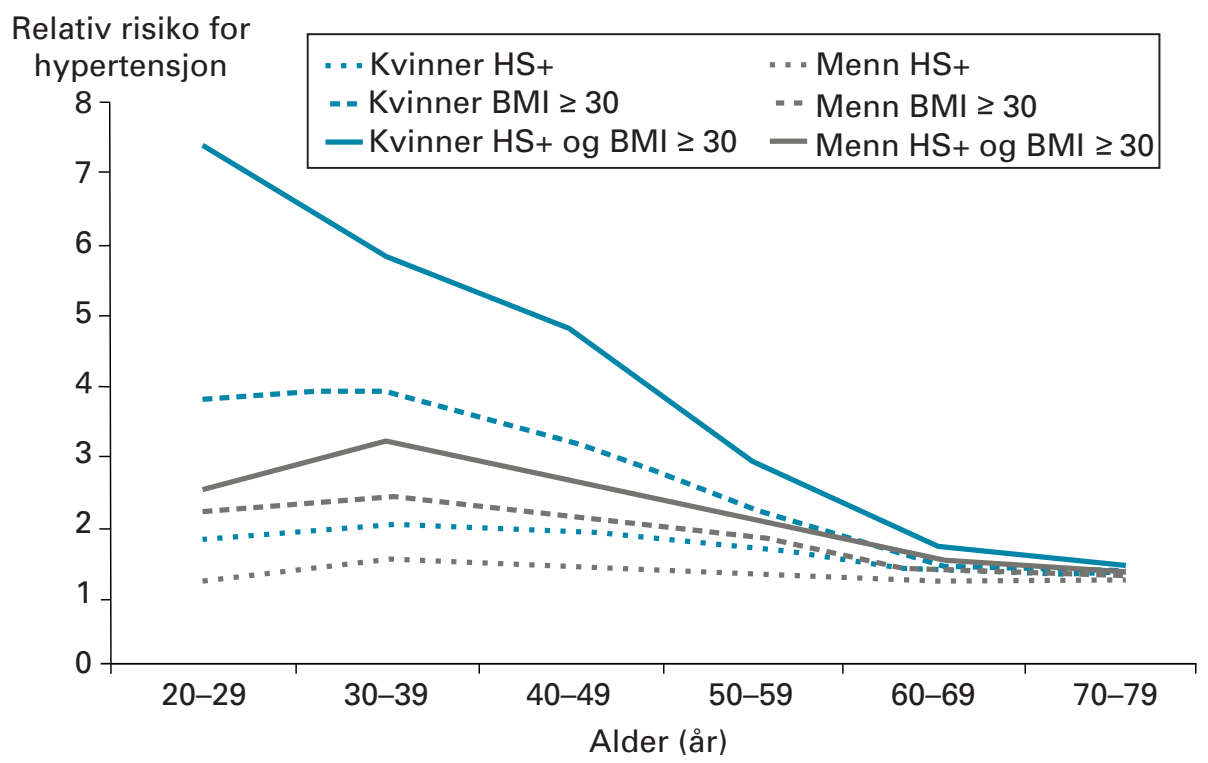

Figur 2 Relativ risiko for hypertensjon ved BMI $\geq 30 \mathrm{~m} / \mathrm{kg}^{2}$ og/eller hypertensjon i slekten (HS+) i forhold til en referansegruppe med $B M I<25 \mathrm{~m} / \mathrm{kg}^{2}$ uten hypertensjon i slekten (HS-) ( $\mathrm{n}=42$ 117) for seks alderskategorier 
Tabell 3 Karakteristikk av 30577 deltakere uten blodtrykksmedikasjon med komplett datasett angitt som gjennomsnittsverdi (SD) og prosentandel

\begin{tabular}{|c|c|c|c|}
\hline Variabel & $\begin{array}{c}\text { Totalt } \\
\text { (n }=30577)\end{array}$ & $\begin{array}{c}\text { Kvinner } \\
(\mathrm{n}=16395)\end{array}$ & $\begin{array}{c}\text { Menn } \\
\text { (n= } 14 \text { 182) }\end{array}$ \\
\hline Alder (år) & $43,1(13,9)$ & $42,1(13,5)$ & $44,4(14,2)$ \\
\hline Systolisk blodtrykk (mm Hg) & $131,9(17,8)$ & $127,8(18,1)$ & $136,6(16,2)$ \\
\hline Diastolisk blodtrykk (mm Hg) & $78,0(11,2)$ & $76,0(10,7)$ & $80,4(11,2)$ \\
\hline Blodtrykk $\geq 140 / 90 \mathrm{~mm} \mathrm{Hg}(\%)$ & 30,9 & 22,7 & 40,4 \\
\hline \multicolumn{4}{|l|}{ Egen sykdom (\%) } \\
\hline Hjerneslag & 0,6 & 0,4 & 0,7 \\
\hline Angina pectoris & 1,6 & 0,8 & 2,5 \\
\hline Hjerteinfarkt & 1,1 & 0,4 & 2,0 \\
\hline Diabetes mellitus & 1,2 & 0,9 & 1,5 \\
\hline \multicolumn{4}{|l|}{ Sykdom i slekten (\%) } \\
\hline Hjerneslag & 16,8 & 16,9 & 16,6 \\
\hline Hjerteinfarkt & 14,9 & 15,6 & 14,2 \\
\hline Diabetes mellitus & 16,7 & 17,0 & 16,3 \\
\hline Hypertensjon & 37,3 & 40,8 & 33,2 \\
\hline \multicolumn{4}{|l|}{ Utdanningsstatus (\%) } \\
\hline Høy & 38,1 & 41,3 & 34,4 \\
\hline Lav & 61,9 & 58,7 & 65,6 \\
\hline \multicolumn{4}{|l|}{ Fysisk aktivitetsnivå (\%) } \\
\hline Høyt & 6,3 & 4,6 & 8,4 \\
\hline Lavt & 93,7 & 95,4 & 91,6 \\
\hline \multicolumn{4}{|l|}{ Røykestatus (\%) } \\
\hline Aldri røykt & 46,2 & 47,5 & 44,8 \\
\hline Tidligere røyker & 24,3 & 21,0 & 28,2 \\
\hline Nåværende røyker & 29,5 & 31,6 & 27,0 \\
\hline Kroppsmasseindeks $\left(\mathrm{kg} / \mathrm{m}^{2}\right)$ & $25,84(3,85)$ & $25,55(4,23)$ & $26,18(3,31)$ \\
\hline \multicolumn{4}{|l|}{ BMI-nivå $\left(\mathrm{kg} / \mathrm{m}^{2}\right)(\%)$} \\
\hline$<25$ & 45,1 & 51,2 & 37,9 \\
\hline $25-30$ & 42,2 & 35,2 & 50,2 \\
\hline$\geq 30$ & 12,8 & 13,6 & 11,8 \\
\hline Bruker alkohol (\%) & 92,4 & 90,8 & 94,2 \\
\hline
\end{tabular}

valens av hypertensjon tilsvarende det å gå opp en BMI-klasse.

Vi finner at den relative forekomsten av hypertensjon assosiert med hypertensjon i slekten og fedme er høyest i ung alder. Dette var tydeligst for kvinner (fig 2). For kvinner i alderen 20-29 år fant vi også en statistisk signifikant positiv interaksjon mellom hypertensjon i slekten og fedme, mens effekten av å ha begge disse risikofaktorene i resten av kohortene kan betraktes som additiv. At overvekt og fedme har spesielt sterk sammenheng med prevalens av hypertensjon i ung voksen alder, er sammenfallende med funn i andre undersøkelser av barn og ungdom (17). Tiltak mot overvekt kan derfor være spesielt viktig hos unge - det vil ha størst effekt på sykdomsfrie leveår og levetid hvis tiltakene lykkes.

Det var mindre sterke sammenhenger med de andre livsstilsrelaterte risikofaktorene. Det er veldokumentert at data om selvrapportert fysisk aktivitet er upålitelige (18), spesielt gjelder det overvektige, som kan ha en tendens til å overvurdere sin egen aktivi- tet (19). Dette kan være en av årsakene til at fysisk aktivitet ikke var statistisk signifikant assosiert med blodtrykksnivå i denne undersøkelsen. Fysisk aktivitet er tidligere blitt testet $\mathrm{i}$ tre ulike aktivitetsnivåer, men resultatene ble da tilsvarende som inndeling $i$ to nivåer $(9,10)$. I tidligere studier har man valgt høy aktivitet som referansekategori for fysisk aktivitet (9). I denne studien ser vi at ved deling $\mathrm{i}$ to nivåer faller nesten alle $\mathrm{i}$ det lave nivået. Det ville derfor blitt meget få personer i hver gruppe dersom høyt aktivitetsnivå ble differensiert ytterligere.

Både tidligere og nåværende røykere hadde lavere systolisk blodtrykk enn ikke-røykere. Hvordan røyking påvirker blodtrykket, er omdiskutert. Noen har hevdet at røykeslutt på lang sikt gir økt blodtrykk og økt risiko for hypertensjon (20), mens andre ikke har funnet noen sammenheng mellom røykeslutt og blodtrykksnivå (21). Personer med lavere utdanning hadde høyere blodtrykk enn dem med høyere utdanning, noe også andre har funnet (22). I denne tverrsnittsstudien har personer med koronar hjertesykdom en tendens til lavere blodtrykk, mest forenlig med medisinering for sykdommen som kan ha blodtrykksreduserende effekt.

En styrke ved denne studien er at den er basert på data fra en befolkningsundersøkelse med høyt oppmøte i en populasjon som er stabil og etnisk homogen og derfor egnet til epidemiologiske studier. Svakhetene med studien omfatter bruk av spørreskjema, som kan være en feilkilde på grunn av muligheter for feilavkryssing, strategiske svar og manglende data. Blant annet manglet det opplysninger om aktuelle sykdommer i familien hos ca. $30 \%$. Studiepopulasjonene var likevel store nok til at analysene kunne utføres, og i undersøkelsen av forekomst av hypertensjon fant vi ingen forskjell mellom inkluderte og ekskluderte individer kontrollert for alder. Vi inkluderte alle tilgjengelige forklaringsvariabler som vi mente var relevante for problemstillingen i regresjonsanalysene. En svakhet med denne fremstillingen er at sterk samvariasjon mellom forklaringsvariablene kan skjule interessante sammenhenger mellom blodtrykket og hver enkelt forklaringsvariabel og dessuten gjøre modellen ustabil. Vi undersøkte derfor samvariasjon mellom sykdommer i slekten og egenopplevd sykdom. Disse sammenhengene var moderate og påvirket ikke resultatene i nevneverdig grad (data ikke vist).

$\mathrm{Vi}$ ser det som en styrke at alle variablene vi anså som klinisk relevante ble inkludert i regresjonsmodellene. Noen av disse er ikke statistisk signifikante og representerer uventede negative funn. Svakheten ved å inkludere andre antatt mindre relevante variabler som ved univariatanalyser viser seg å være statistisk signifikante, er at disse kan representere tilfeldige funn og vanskelig kan brukes til å styrke eller svekke nullhypoteser. Ut fra en helhetsvurdering valgte vi ikke å gjøre det.

Blodtrykksmålingen ble gjort ved bare én konsultasjon, som er vanlig ved store befolkningsundersøkelser, og ikke tre ganger, som er kravet for diagnoseblodtrykk (23). Måleapparatet som ble brukt er validert (24), og ved valg av mansjettstørrelse tok man hensyn til overarmens omkrets (8). Gjennomsnittlig blodtrykk $(137,9 / 80,3 \mathrm{~mm} \mathrm{Hg})$ og prevalens av hypertensjon (44,9\%) i HUNT 2 tilsvarer verdier som er funnet $i$ andre studier fra nordiske og nordeuropeiske land (25). Blod- og urinanalyser ble ikke inkludert og derfor ikke kontrollert for.

Helseundersøkelsen i Nord-Trøndelag (HUNT) er et samarbeidsprosjekt mellom HUNT forskningssenter (Det medisinske fakultet, Norges teknisknaturvitenskapelige universitet), Nord-Trøndelag fylkeskommune og Nasjonalt folkehelseinstitutt. Det rettes en spesiell takk til HUNT forskningssenter $i$ Verdal for deres bidrag med å tilrettelegge databasen.

e-tab 2 på www.tidsskriftet.no 
Tabell 4 Multippel lineær regresjon med systolisk blodtrykk som avhengig variabel for 30577 kvinner og menn uten blodtrykksmedikasjon og med komplett datasett

\begin{tabular}{|c|c|c|c|c|}
\hline \multirow[b]{2}{*}{ Variabel } & \multicolumn{2}{|c|}{ Kvinner ( $n=16$ 395) } & \multicolumn{2}{|c|}{ Menn (n = 14 182) } \\
\hline & Koeffisient ${ }^{1}$ & P-verdi & Koeffisient ${ }^{1}$ & P-verdi \\
\hline Alder per år & 0,550 & $<0,001$ & 0,333 & $<0,001$ \\
\hline \multicolumn{5}{|l|}{ Sykdom i slekten } \\
\hline Hjerneslag & $-0,087$ & 0,799 & 0,734 & 0,039 \\
\hline Hjerteinfarkt før 60 år & $-0,163$ & 0,630 & $-0,170$ & 0,644 \\
\hline Diabetes & 0,150 & 0,654 & $-0,526$ & 0,137 \\
\hline Hypertensjon & 3,089 & $<0,001$ & 2,762 & $<0,001$ \\
\hline \multicolumn{5}{|l|}{ Egenopplevd sykdom } \\
\hline Hjerteinfarkt & $-2,650$ & 0,226 & $-2,319$ & 0,023 \\
\hline Angina pectoris & $-1,873$ & 0,222 & $-3,310$ & $<0,001$ \\
\hline Hjerneslag & 0,707 & 0,698 & 4,066 & 0,009 \\
\hline Diabetes & 2,675 & 0,040 & 2,492 & 0,017 \\
\hline Lav fysisk aktivitet & 0,147 & 0,800 & 0,798 & 0,082 \\
\hline Lav utdanning & 2,214 & $<0,001$ & 1,952 & $<0,001$ \\
\hline Tidligere røyker & $-2,544$ & $<0,001$ & $-0,798$ & 0,015 \\
\hline Nåværende røyker & $-2,774$ & $<0,001$ & $-1,739$ & $<0,001$ \\
\hline \multicolumn{5}{|l|}{ BMI $\left(\mathrm{kg} / \mathrm{m}^{2}\right)$} \\
\hline $25-29$ & 4,081 & $<0,001$ & 3,549 & $<0,001$ \\
\hline$\geq 30$ & 9,778 & $<0,001$ & 7,031 & $<0,001$ \\
\hline Alkoholbruk & $-1,399$ & 0,001 & $-0,601$ & 0,275 \\
\hline
\end{tabular}

Koeffisientene viser estimert gjennomsnittlig forskjell i blodtrykk ( $\mathrm{mm} \mathrm{Hg}$ ) hos personer med og uten den aktuelle risikofaktor og justert for virkningen av alle de andre risikofaktorene

\section{Morten Klouman (f. 1982)}

er turnuslege på Elverum. Han jobbet med denne artikkelen da han var student ved Det medisinske fakultet ved Norges teknisk-naturvitenskapelige universitet.

Ingen oppgitte interessekonflikter.

\section{Arne Åsberg (f. 1951)}

er dr.med. og spesialist i medisinsk biokjemi og i nukleærmedisin. Han er seksjonsoverlege ved Avdeling for medisinsk biokjemi ved St. Olavs hospital.

Ingen oppgitte interessekonflikter.

\section{Tor-Erik Widerøe (f. 1940)}

har vært leder av Avdeling for nyresykdommer ved St. Olavs hospital og professor II ved Det medisinske fakultet, Norges teknisk-naturvitenskapelige universitet. Er fungerende professor emeritus ved Institutt for kreftforskning og molekylær medisin samme sted. Ingen oppgitte interessekonflikter. tension Society, 2004-BHS IV. J Hum Hypertens 2004; 18: 139-85

7. Selmer R, Lindman AS, Tverdal A et al. Modell for estimering av kardiovaskulær risiko i Norge. Tidsskr Nor Legeforen 2008; 128: 286-90.

8. Holmen J, Midthjell K, Krüger $\emptyset$ et al. The NordTrøndelag Health Study 1995-97 (HUNT 2): objec-
9. Vatten LJL, Nilsen TIL, Holmen JJ. Combined effect of blood pressure and physical activity on cardiovascular mortality. J Hypertens 2006; 24 : $1939-46$.

10. Tjønna AE, Lund Nilsen TI, Slørdahl SA et al. The association of metabolic clustering and physical activity with cardiovascular mortality: the HUNT study in Norway. J Epidemiol Community Health 2010; 64: 690-5.

11. Zou GY. On the estimation of additive interaction by use of the four-by-two table and beyond. Am J Epidemiol 2008; 168: 212-24.

12. Chirinos JA, Franklin SS, Townsend RR et al. Body mass index and hypertension hemodynamic subtypes in the adult US population. Arch Intern Med 2009; 169: 580-6

13. Adams KF, Schatzkin A, Harris TB et al. Overweight, obesity, and mortality in a large prospective cohort of persons 50 to 71 years old. N Engl J Med 2006; 355: 763-78.

14. Williams RR, Hunt SC, Hasstedt SJ et al. Are there interactions and relations between genetic and environmental factors predisposing to high blood pressure? Hypertension 1991; 18 (suppl): 129-37

15. Neter JE, Stam BE, Kok FJ et al. Influence of weight reduction on blood pressure: a meta-analysis of randomized controlled trials. Hypertension 2003; 42: 878-84.

16. Bramlage P. Hasford J. Blood pressure reduction, persistence and costs in the evaluation of antihypertensive drug treatment - a review. Cardiovasc Diabetol 2009; 8: 18

17. Sorof J, Daniels S. Obesity hypertension in children: a problem of epidemic proportions. Hypertension 2002; 40: 441-7.

18. van Baak MA. Exercise and hypertension: facts and uncertainties. Br J Sports Med 1998; 32: 6-10.

19. Leary SD, Ness AR, Smith GD et al. Physical activity and blood pressure in childhood: findings from a population-based study. Hypertension 2008; 51 : 92-8

20. Lee DH, Ha MH, Kim JR et al. Effects of smoking cessation on changes in blood pressure and incidence of hypertension: a 4-year follow-up study. Hypertension 2001: 37: 194-8.

21. Tuomilehto J, Nissinen A, Puska P et al. Longterm effects of cessation of smoking on body weight, blood pressure and serum cholesterol in the middle-aged population with high blood pressure. Addict Behav 1986: 11: 1-9.

22. Yan LL, Liu K, Daviglus ML et al. Education, 15year risk factor progression, and coronary artery calcium in young adulthood and early middle age the Coronary Artery Risk Development in Young Adults study. JAMA 2006: 295: 1793-800.

23. Mancia G, De Backer G, Dominiczak A et al. 2007 ESH-ESC Practice Guidelines for the Management of Arterial Hypertension: ESH-ESC Task Force on the Management of Arterial Hypertension. $J$ Hypertens 2007; 25: $1751-62$.

24. Silas JH, Barker AT, Ramsay LE. Clinical evaluation of Dinamap 845 automated blood pressure recorder. Br Heart J 1980; 43: 202-5.

25. Wolf-Maier K, Cooper RS, Banegas JR et al. Hypertension prevalence and blood pressure levels in 6 European countries, Canada, and the United States. JAMA 2003; 289: 2363-9. tives, contents, methods and participation. Norsk Epidemiologi 2003; 13: 19-32.
Mottatt 22.4. 2010, første revisjon innsendt 27.8. 2010, siste revisjon innsendt 21.3. 2011, godkjent 8.4. 2011. Medisinsk redaktør Mette Sagsveen. 